\title{
Changes in Education under the Influence of Digital Technologies: main Problems and Risk of Division
}

\section{Maria Kiseleva1, Natalia Kiseleva², and Evgeny Kiselev ${ }^{3}$}

${ }^{1} \mathrm{MA}$, ITMO University, St. Petersburg, Russia

${ }^{2} \mathrm{PhD}$, Institute of Physical Culture, Sports and Youth Policy, Ural Federal University, Ekaterinburg, Russia

${ }^{3} \mathrm{PhD}$, Institute of Trade, Food Technologies and Service, Ural State University of Economics, Ekaterinburg, Russia

\section{Abstract}

Digital technologies are rapidly changing the process of education. Online courses have become a common tool of gaining knowledge outside the university. Multimedia education, penetrating traditional educational institutions (schools, colleges, and universities), changes the structure of education and brings new elements to the communications during the educational process. This article considers one level of

Corresponding Author:

Natalia Kiseleva

kisi13.01@mail.ru

Received: Month 2020

Accepted: Month 2020

Published: 28 September 2020

Publishing services provided by Knowledge E

(c) Maria Kiseleva et al. This article is distributed under the terms of the Creative Commons Attribution License, which permits unrestricted use and redistribution provided that the original author and source are credited.

Selection and Peer-review under the responsibility of the Convention-2019 Conference Committee.

\section{G OPEN ACCESS}

change in the model of education. On the one hand, there are advantages associated with the democratization of education. At the time of their foundation, universities were the creators of new elites - scientific and educational meanwhile, in the twenty-first century, the process of democratization and the accessibility of university education has been linked to the digitalization. On the other hand, territorial and other restrictions have been lifted. And this is a very controversial process that poses many challenges for students, one of the most noticeable of which is the lack of real contact with the teacher and the transformation of the educational process into an "educational conveyor belt." At the same time, personal contact with the teacher is becoming more expensive. The authors have collected studies that examine the dynamics of this emerging stratification of education. Based on the work of the pioneers in the study of digital education, the authors develop their ideas, focusing on the formation of the modern models of education, defined as affordable electronic and elite traditional.

Keywords: online courses, online education, MOOC

\section{Introduction}

In the past two decades, the concept of online education has penetrated our life, since taking online courses and seminars, graduating from online schools and universities, and even getting a degree [1] became possible without leaving home. At first, it was perceived as an entertainment, as another game that virtual reality offers, not really connected with a great tradition called "getting an education", usually associated with the walls of universities and professors' faces. A little time passed, and gradually, online education (whether it be part of MOOC (massive open online courses) or individual seminars) has become a familiar way of gaining knowledge in the modern life. 
The most significant and well-recognized example is the Coursera.org project, created in 2011, and which in 2015 totaled 12 million registered users, 28 million in 2017, and 36 million in 2018 [2]. Russia is also not far behind its Western counterparts: Russia's largest educational platform Open Education (“Otkrytoe obrazovanie") involved 581,000 students and more than 250 courses were offered by the country's leading universities in 2018 (in 2019, the number of courses increased up to 350 [3]). The multimedia resources and opportunities that multimedia education offers are becoming the subject of scientific reflection [4]. However, the use of MOOC is relatively new in the traditional university system in Russia. We argue that only by emphasizing the challenges that technology brings to education and by taking into account the experience of our Western colleagues, the problems that may arise in the future can be averted.

\section{Discussion}

As a rule, the positive aspects of online education are mentioned, such as access to electronic textbooks and electronic encyclopedias, as well as open databases of scientific publications which make available an unthinkable amount of information. Education, in its turn, took up the challenge and began to interact with the changing sources of information, and digital technology found its ground in education. This double-sided interaction expanded the generally accepted concept of education in its academic sense: technology allowed education to "go beyond" the material walls of schools and universities, expanding the educational space to previously unprecedented sizes - virtual reality became a part of the educational system. Video games, online educational courses and video lectures have carved their way, and most of them were created by universities themselves. The opportunity to get knowledge from anywhere in the world, if there is Internet access, is perceived as an unconditional benefit of the digital era.

Moreover, because of rapid worldwide Internet spreading, education can be now considered truly affordable. There is no need any more to provide students with the classrooms. Even teachers are becoming less necessary, though they still perform what the machine is not yet subject to, e.g. checking tests and giving qualitative feedback to students. Therefore, amounts of money are saved which were usually spent on salaries. It suffices to compare: getting a Master's degree at the elite Harvard University (the 6th place at THE World University Ranking [5] and the 3rd place in QS World University Ranking [5] will cost approximately 50,000 dollars [5], at the same time getting the same 
degree online (with the possibility of attending classes offline) at Harvard Extension School costs about 30,000 dollars [6].

In addition, online education makes it possible to provide access to university to people who cannot afford traditional classes, e.g. people having full-time job or young children. They can get a quality education or even develop new skills, which was hardly possible in the pre-Internet era. Besides, digital education, which is especially important, is becoming a truly mass education. According to the aggregator Class Central [2], the number of students around the world, who have mastered at least one online course, is growing like an avalanche - from 30 million in 2015 to 70 million in 2017.

Digital education became an opportunity, a tool for solving problems of education, which, unfortunately, are not overcome in the 21-century world. Technology provides open access to knowledge and different courses offered even by the elite universities. Technology has made education cheaper and more affordable to every person who has the Internet connection and desire to learn. In other words, open online courses stimulate the democratization of education. Benefits that digital education gives seem to be inconceivable.

However, distance education still raises a lot of questions. Various researchers began to deal with issues of changing educational models and the problems associated with these changes. For example, in her research Shanna Smith Jaggars described how the students get online education and it changes the traditional teacher-student interaction. The researcher notes that the main problem with online courses is that up to 90 percent of students do not complete the courses, most likely due to lack of motivation, especially if the courses are not obligatory and a mark is not required. Nevertheless, the picture is the same with obligatory college courses. For example, the 2012 study conducted at 57 colleges in Virginia and Washington among students who took compulsory online courses shows that the percentage of online courses completion is noticeably lower than traditional ones: "Completion rates in face-to-face courses were 81 percent, while online completion rates were 68 percent in Washington, the rates of completion were 90 percent for face-to-face versus 82 percent for online" [7].

Another problem is the lack of traditional face-to-face contact with the teacher, which is the source of motivation for many students. Online education may not be suitable for people who are having difficulty with learning on their own, as well as for those who definitely need contact with a teacher to succeed. Interestingly, students who have difficulties with online courses can easily name sources of their low performance: "Students told us that they received less instructor guidance, support, and encouragement in their 
online courses; as a result, they did not learn the material as well" [7]. This statement creates a broad space of reflection, and, hence, tools for online learning improvement.

Another study conducted at Columbia University [8] found out that the local college students, who took online courses, were much more likely to fail or refuse to attend the course, compared to the students in traditional classes. They spent earned money on courses and received nothing instead. Ineffective students who barely succeeded in the traditional format, as a rule, lagged behind when took online courses. These students lacked confidence and competence, since they required interaction with their teachers to feel comfortable and succeed. What they often got online was an alienation from the teacher, who could rarely contact them directly.

In another study, published by the Revealing Institutional Strengths and Challenges (RISC) [9], students called online courses one of the main problems they had to deal with during their studies. Online courses followed immediately after combining work and study, problems with money, and the high expectations of parents. According to Porter and Umbach, "of the $21 \%$ who indicated online classes presented a challenge to their success, just over half had difficulty learning the material on their own, something expected in courses delivered in an online environment. Approximately $44 \%$ were challenged by the lack of interaction with their online faculty. One student summarized this well: "From my experience, I struggle in online classes, but succeed in regular classes" [9].

All this leads to a logical, but not the most pleasant comparison: mainly, online learning is built on the conveyor system, which simplifies and automates the learning process while focusing on obtaining an average result. Education becomes akin to the production of fast food with a clearly tuned algorithm (completely non-human oriented), and learners and educators are given a limited range of average quality products as a result. All the examined studies emphasize a lack of interaction with the teacher, need for a personal approach, and, probably an individual care.

Bowles Nellie studied a new model of teacher-student interaction in online education. He noted that the most important achievement in this Internet technological revolution was its democratic nature. A very acute problem noted by Bowles Nellie was the discomfort of the new status of a student being without a teacher: students feel uncomfortable without teachers' supervision, lacking motivation and incapable of completing the online course. Education uniqueness disappears, and the teacher, who assists and guides to the world of education as a representative of "life" knowledge, is replaced more often with a static online course. An algorithm does not take into 
account individual characteristics of the student and is only aimed at the result and reproducibility.

The example that New York Times cites in the article "Human Contact Is Now a Luxury Good" [10] requires special attention. In Silicon Valley, the private Waldorf schools, which abolished the use of technology, are gaining more and more popularity. These schools manifest a "return to nature": in the classroom special attention is paid to craft, physical activity, creative tasks, and building trustful contacts between the teacher and the student. At the same time, students do not undergo standard procedures for "measuring knowledge", as there are no tests (except for graduation ones). In the most famous Waldorf School of the Peninsula, the use of gadgets (smart-phones) is prohibited until the end of the 8th year. Certainly, there is no possibility for online courses, although out of 200 students, $75 \%$ have at least one parent working in high technology. According to 2011 , the cost of education is $\$ 17,750$ per year for kindergarten until the 8 th year and $\$ 24,400$ per year for high school [11]. A Google review of this school says, "If you can afford it, take it."

Thus, we can assume that attempts are being made to return the elitist nature of education, excluding digital technologies from it and trying to create a new isolation. There is at least one advantage - the parallel improvement of the provision of personal services, as expensive services are always customized. This approach is individual and flexible, and moreover, it supports strict and high standards of service taking into account the level of customers' requirements. So, there is no return to traditional forms - there is a further modification of services in educational models of the modern society.

\section{Conclusion}

The results of the study show that a certain dynamics of stratification and changes in the model of education are recorded. Obviously, this is the way from the elitism of full-time university education, accessible only to young people who applied to the university, through the emergence of other forms of university education: correspondence, when education becomes available to new groups of people (working, young mothers, etc.), distance, which allowed the inclusion of the new territories in the process of higher education. And with the advent of electronic education, the elitism of university education disappears - education becomes available to all groups and all territories where there is a worldwide network.

What emerges is what is called education in the era of "literacy" - this makes online education possible. A comparative analysis of education models in different 
studies shows that it was online education that made it cheaper and made "lifelong education" real. At the same time, the traditional "individual education of teachers and students have a real risk of becoming an expensive and exclusive service, while students attending online courses suffer from a lack of interaction with a real teacher, being afraid of becoming a part of the "educational conveyor". But poorly designed courses can seriously impede students.

The danger of a new stratification of educational models requires serious further study and modification of online courses, when democratic access is combined with the setting and convenience of personal access to education.

\section{Conflict of Interest}

The authors have no conflict of interest to declare.

\section{References}

[1] Murphy, A. (2019, March 13). 5 Reasons to Study Online. Retrieved April 14, 2019 from https://www.onlinestudies.com/article/5-reasons-to-study-online/

[2] Chopra, A., (2019, February 12). Coursera Product Updates. Retrieved April 14, 2019 from https://blog.coursera.org/introducing-coursera-plus-a-subscription-planfor-unlimited-learning/

[3] Otkrytoe obrazovanie (2015). O proekte «Nationalnaya platform Otkrytogo obrazovaniya ». Retrieved from https://npoed.ru/about

[4] Goodova, M., Rubtsova, E. and Fernandez, R. F. F. (2015). Multimedia Resources as Examples of Polymorphic Educational Hypertexts in the Post-Literacy Era. Procedia - Social and Behavioral Sciences, issue 214, pp. 952-957.

[5] Times Higher Education (2019, January 5). World university rankings 2019. Retrieved April 2, 2019 from https://www. timeshighereducation.com/world-university-rankings/2019/worldranking\#!/page/O/length/25/sort_by/rank/sort_order/asc/cols/stats

[6] Harvard University (March 14, 2019). Advanced Leadership Program. Retrieved April 21, 2019 from https://advancedleadership.harvard.edu/search/site/ Harvard\{\%\}20Extension\{\%\}20School\{\%\}20?\&solrsort=\{\%\}20

[7] Jaggars, S.S. (2014, Winter). Democratization of Education for Whom? Online Learning and Educational Equity. Vol 17. No. 1. Retrieved March 30, 2019 from https://www.aacu.org/diversitydemocracy/2014/winter/jaggars 
[8] The Trouble with Online College (2013, February 18). Retrieved April 12, 2019 from https://www.nytimes.com/2013/02/19/opinion/the-trouble-with-online-college.html

[9] Porter, S. R. and Umbach, P. D. (2019). What Challenges to Success do Community College Students Face? Raleigh: Percontor, LLC. Retrieved March 14, 2019 from https://www.risc.college/sites/default/files/2019-01/RISC_2019_report_natl.pdf

[10] Bowles, N. (2019, March 23). Human Contact Is Now a Luxury Good. Retrieved April 14, 2019 from https://www.nytimes.com/2019/03/23/sunday-review/human-contactluxury-screens.html

[11] Niche (2019). Waldorf School of the Peninsula - Mountain View Campus. Retrieved May 1, 2019 from https://www.niche.com/k12/waldorf-school-of-the-peninsula--mountain-view-campus-mountain-view-ca/ 